January

\title{
EFFECT OF SMALL-SCALE IRRIGATION ON THE INCOME OF RURAL FARM HOUSEHOLDS: THE CASE OF LAELAY MAICHEW DISTRICT, CENTRAL TIGRAY, ETHIOPIA
}

\author{
Kinfe Aseyehegn, Chilot Yirga and Sundar Rajan
}

\begin{abstract}
Agricultural intensification is presumed to be a necessary pre-condition for the development of the agricultural sector in Ethiopia. To this end, various government and non-governmental organizations (NGOs), among others, initiated small-scale irrigation schemes throughout the country including the Tigray region. Despite these efforts, however, smallholder farmers particularly in the study area are found to be reluctant to participate in small-scale irrigation schemes. This study therefore, assessed the factors that affect smallholder farmers' participation in small-scale irrigation of the study area. It also explored the effect of participation in small-scale irrigation on the income of rural farm households. A two-stage sampling procedure was used to first select peasant associations and then sample respondents. Descriptive statistics and Heckman's twostage estimation were used to estimate determinants of small-scale irrigation participation and household income. The analysis revealed that income, gender, access to market information and health condition of households are important determinants for participating in small scale irrigation schemes. The analysis further revealed that irrigation participation, family labor force, livestock ownership and access to market information and credit are positively and significantly associated with household income. Hence, improving rural farm households' access to market information and health services, is likely to improve participation in irrigation schemes thereby improve small holder farmers income.
\end{abstract}

Keywords: Small-scale Irrigation; Income; Rural Farm Households; Ethiopia

\section{INTRODUCTION}

Ethiopia is predominantly an agrarian country with the vast majority of its population directly or indirectly involved in agriculture. Agriculture in the country is mostly small- scale, rainfall dependent, traditional and subsistence farming with limited access to technology and institutional support services (Desta, 2004).

The development of small-scale irrigation is one of the major intervention areas to boost agricultural production in the rural parts of the country. This helps poor farmers to overcome rainfall and water constraint

\footnotetext{
${ }^{1}$ Institute of Environment, Gender and Development Studies, Awassa College of Agriculture, Hawassa University, Ethiopia

${ }^{2}$ Senior Researcher, Ethiopian Institute of Agricultural Research (EIAR), Ethiopia

${ }^{3}$ Professor, Department of Rural Development and Agricultural Extension, Haramaya University, Ethiopia
} 
The Journal of Agricultural Sciences, 2012 vol. 7, nol

by providing a sustainable supply of water for cultivation and livestock, strengthen the base for sustainable agriculture, provide increased food security to poor communities through irrigated agriculture and contribute to the improvement of human nutrition(FAO, 2003). Though the country has 4.5 million ha of irrigable land, irrigation covers only 0.16 million ha or about 5 percent of the total irrigable land. The dependence of most of the farmers on rain-fed agriculture has made the country's agricultural economy extremely fragile and vulnerable to the impacts of weather and climatic variability leading to partial or total crop failure, which in turn resulted in food shortages (MoWE, 2011).

Tigray is one of the most land-degraded states of Ethiopia .The region is characterized by subsistence farming households raising predominantly cereal and vegetable crops for local consumption and sale. Crop production in the region has failed to keep pace with population growth due to recurrent droughts, environmental degradation and wars, including the most recent conflict with Eritrea (Ersado, 2005). In response to severe environmental degradation and population-resource imbalance, the regional government of Tigray has initiated a major rural development program called Sustainable Agricultural and Environmental Rehabilitation of Tigray (SAERT), through which several smallscale dams have been, constructed
(Ersado et al., 2004). A major land distribution throughout the region was undertaken after the fall of the Derg regime by Ethiopian People Revolutionary Democratic Front (EPRDF) in 1990. However, specific to the study area where three micro irrigation dams exist, land redistribution locally called shigshig was done immediately after the construction of the dams was completed based on the needs of the farmers to balance participation in irrigation. Farm households within the peasant association, which had farmland, were given equal opportunity to own irrigated land. However, some farm households disregarded to possess parcels in the irrigable section of the peasant association at will. Therefore, the objectives of this study are:

- To assess the basic socio-economic and institutional factors that influence small-scale irrigation utilization by small-scale farmers in the study area

- To explore the effect of small-scale irrigation participation on the income of small holder rural farm households

\section{MATERIALS AND METHODS}

\section{Description of the Study Area}

The study area, Laelay Maichew district is found in central zone of Tigray National Regional State. Axum, center of the district and the central zone of Tigray, is located at about $1000 \mathrm{~km}$ north of Addis Ababa. The altitude of 
Kinfe Aseyehegn, Chilot Yirga and Sundar Rajan

the district ranges from 1200-2050 meters above sea level. The district is classified into two agro-climatic zones: mid altitude covers $82 \%$ and low land, area covers $18 \%$ of the total area of the district. In this area irrigation agriculture is practiced with different sources of water for irrigation. In the 2008/09 cropping season, a total of 986 hectares of land has been cultivated through irrigation.

\section{Sample and Sampling Design}

A two stage sampling procedure was followed to first select peasant associations and then sample households. In the first stage, three peasant associations where the three micro-dams were found were selected purposively. Before selecting household heads to be included in the sample, the sampling frame was stratified into irrigation water user and non-user households. The stratum of irrigation user consists of households who own, rented/shared in/out or gifted in land for direct utilization. The second stratum referred to hereafter as non-users is composed of households who neither owned irrigated land nor involved in irrigation farming. In the second stage, 130 farm households consisting of 65 irrigation users and 65 non-users were selected from the identified list using simple random sampling technique taking into account probability proportional to size of the identified households in each of the three selected peasant associations.

\section{Data Collection and Analysis}

A structured interview schedule supported by personal observations of physical features was used to collect primary data. In addition to primary data, secondary data were collected from the District Offices of Irrigation Development (DOID) and District Offices of Rural and Agricultural development (DORAD).

Descriptive statistics (mean, frequency, percentage and standard deviation) and Heckman's two stage estimation were used to analyze the collected data. The statistical significance of the variables in the descriptive part was tested for both dummy and continuous variables using chi-square and t-test, respectively.

Evaluating the effect of a program, in this case participation in irrigation, on an outcome variable (income) using regression analysis such as logit and probit models can lead to biased estimates if the underlying process which governs selection into the institution or a program is not incorporated in the empirical frame work. One solution to this problem in econometrics is the application of Heckman's two-step procedures through controlling of sample selection biases (Wooldridge, 2002; Zaman, 2001).

The first stage of Heckman's two stage model is 'irrigation participation equation' that captures the factors governing participation employing a 
The Journal of Agricultural Sciences, $2012 \mathrm{vol} .7$, nol

binary probit equation. This equation is used to construct a selectivity term known as the 'Inverse Mills ratio (Lambda), which is added to the second stage 'outcome' equation or" income". If the coefficient of the 'selectivity' term is significant then the hypothesis that an unobserved selection process governs the participation equation is confirmed.

\section{RESULTS AND DISCUSSION}

\section{Socio-Demographic Characteristics of the Households}

Age of the household heads of sample respondents ranged from 28 to 80 years with mean of 50.22 and standard deviation of 11.04 years for small- scale irrigation users. For non-users the mean and standard deviation happens to be 47.12 and 12.859 years, respectively (Table 1). The age difference between the two groups, however, is found to be statistically insignificant suggesting age has very little influence on the participation decision.

Gender of the household head is an important variable influencing the participation decision in irrigation. The total sample of the study is composed of $20 \%$ female headed households while the portion of female headed households who are irrigation users is reduced to $12 \%$. Discussion with sample households revealed that maleheaded households hardly faced labor shortage for irrigation as well as rainfed farming due to physical, technological, socio-cultural and psychological fitness of farm instrument to males than females. Similarly, education plays a key role for household decision in technology adoption. It creates awareness and helps for better innovation and invention. The study revealed that $40 \%$ of the users and $60.8 \%$ of the non-users of small-scale irrigation are illiterate. It is also found that the number of irrigation users who completed nine years of schooling and above is twice as compared to nonusers.

The average household size for the users and non-users of small-scale irrigation is found to be 6.43 and 5.15 , respectively. This result is statistically significant suggesting labor availability is an important factor influencing households' decision to participate in small-scale irrigation schemes. The result also revealed, as active family labor or work force of a household in adult equivalent increases, the total income of the household increases, which in turn contributed to improved well-being, further providing an evidence for the importance of labor availability in influencing the participation decision of households in small-scale irrigation. 
Kinfe Aseyehegn, Chilot Yirga and Sundar Rajan

Table 0 1: Summary of demographic characteristics of household heads

\begin{tabular}{|c|c|c|c|c|c|c|c|}
\hline \multirow[t]{2}{*}{ Sex } & \multicolumn{2}{|c|}{ User } & \multicolumn{2}{|c|}{ Non-user } & \multicolumn{2}{|c|}{ Total } & \multirow[t]{2}{*}{$\chi^{2}$} \\
\hline & $\mathrm{N}$ & $\%$ & $\mathrm{~N}$ & $\%$ & $\mathrm{~N}$ & $\%$ & \\
\hline Female & 8 & 12.3 & 18 & 27.7 & 26 & 20 & \\
\hline Male & 57 & 87.7 & 47 & 72.3 & 104 & 80 & $3.894 * *$ \\
\hline & mean & st.dev & mean & st.dev & Mean & st.dev & T-value \\
\hline Age ( years) & 50.22 & 11.04 & 47.12 & 12.859 & 48.67 & 12.038 & 1.471 \\
\hline Education & 2.26 & 2.917 & 1.49 & 2.646 & 1.88 & 2.801 & 1.575 \\
\hline (years) & 6.43 & 2.038 & 5.15 & 1.946 & 5.79 & 2.086 & $3.653 * * *$ \\
\hline Family size & 3.71 & 1.665 & 2.57 & 1.468 & 3.14 & 1.665 & $4.135^{* * *}$ \\
\hline Family labor & & & & & & & \\
\hline
\end{tabular}

Irrigation labor force is the amount of labor needed for irrigation activities. Similarly, rain-fed labor is the labor required for rain-fed activities. Irrigated and rain-fed agriculture requires diverse labor force both in quantity and technical quality. Findings from the study demonstrated $44.6 \%$ of the users of small-scale irrigation faced labor shortage for irrigation activities while $30.9 \%$ of the users and $24.6 \%$ of the non-users faced labor shortage for rainfed activities. Farm households who faced labor shortage employ different mechanisms to acquire additional labor required for accomplishing farm activities. A total of $76.9 \%$ and $23.1 \%$ of the irrigation users, who faced labor shortage, acquired additional labor through hiring and labor exchange mechanisms, respectively. Likewise, $77 \%$ and $23 \%$ of the labor deficient irrigation users used hired and exchange labor, respectively, to solve the problem of labor shortage for rain-fed farming.
Similarly, a total of $24.6 \%$ and $75.4 \%$ of the labor deficient irrigation nonusers used hired and exchange labor for rain-fed farm activities. It is worth to note that $35.4 \%$ of the casual labor employed in irrigation farming was source from the non-users of irrigation within the kebele/ wereda whereas $64.6 \%$ were from nearby kebele/woredas that are very low in irrigation sources. This proves irrigation intensifies labor and is preeminent strategy of employment in countries like Ethiopia with elevated population growth rates. Irrigation user households also compared the labor consumption ratio of irrigated farming to rain-fed farming, which accounts $12.3 \%, 70.8 \%$, $15.4 \%$ and $1.5 \%$ as equal, two times, three times and four times respectively. The farm households replied from the point of view of their activities and economy. The response of equal and three or four times ratio is from the farm families specialized on cereal and vegetable crops respectively in their 
The Journal of Agricultural Sciences, 2012 vol. 7, nol

irrigated farm and two times is from the farm households which diversified on cereal and vegetable crops. This reveals that the labor consumption for vegetable farming is double as compared with cereal crops.

\section{Resource Ownership and Farm Experience}

Irrigation user and non-user households of the area have an average land size of 1.1 and 0.627 irrigated and rain-fed hectares respectively. Resource ownership and farm experience have a profound effect on the participation decision-making behavior of farm households. The variables experience in rain-fed farming and rain-fed land holding pertain to both users and nonusers of small-scale irrigation while the variables irrigation experience and irrigable land holding pertain to users only. Therefore, the survey results revealed that $10.8 \%$ of the users of irrigation do not own rain-fed land at all. On the other hand, of the total respondents, $4.6 \%$ of the users and $7.7 \%$ of the non-users do not own land but cultivated land obtained through sharecropping arrangements. Findings of the survey revealed that $58.5 \%$ of the users and $17 \%$ of the non-users shared in land, while $16.9 \%$ of the users and $24.6 \%$ of the non-users shared out their own land. This shows that irrigation users are better off practicing land shared in than non-users are. The land shortage and searching for additional land is the motivating factor for shared in. The non-users of small-scale

Table 0 2: Land ownership and farm experience of respondents

\begin{tabular}{lllll}
\hline & \multicolumn{2}{c}{ Users } & \multicolumn{2}{c}{ Non-users } \\
\hline & Frequency & Percent & Frequency & Percent \\
Shared in & 38 & 58.5 & 11 & 17 \\
Shared out & 11 & 16.99 & 16 & 24.6 \\
& & & \\
Reasons for not using irrigation & & 17 & 26.2 \\
Land shortage & & 21 & 32.4 \\
Limited information & & 27 & 41.4 \\
Have fertile rain-fed land & & &
\end{tabular}

\begin{tabular}{lllll} 
Land holding in ha. & User & Non-user & Total & t-value \\
\cline { 2 - 5 } & Mean & Mean & Mean & \\
Total cultivated land & 1.1 & 0.627 & 0.856 & $5.826^{* * * *}$ \\
Irrigable land & 0.5 & 0.000 & 0.247 & $13.531^{* * *}$ \\
Rain-fed land & 0.6 & 0.627 & 0.608 & 0.546
\end{tabular}

Farm experience in years

\begin{tabular}{lllll} 
Rain-fed & 33.37 & 29.68 & 31.52 & $1.706^{* *}$ \\
Irrigation & 11.86 & 0.000 & 5.93 & $14.757^{* * *}$ \\
\hline
\end{tabular}

$* * *$ and $* *$ statistically significant at $1 \%$ and $5 \%$ probability level respectively

Source: Survey data, 2009 
Kinfe Aseyehegn, Chilot Yirga and Sundar Rajan

irrigation have different reasons for rejecting irrigation utilization. From the total irrigation non-user households, $26.2 \%$ and $32.4 \%$ eschewed from utilization due to lack of farmland at the time of redistribution and information on irrigation respectively. On the other hand, $41.4 \%$ of them is due to their expectation that the rain-fed land they owned is too fertile and can produce better.

Directly or indirectly irrigation and irrigation dams have positive consequences on food security, asset ownership and well-being of rural farm households. Increased in agricultural production through diversification and intensification of crops grown, increase household income because of on/off/non-farm employment, source of animal feed, improving human health due to balanced diet and easy access and utilization for medication, soil and ecology degradation prevention and asset ownership are contributions of irrigation.

\section{Income Distribution and Inequalities of the Households}

Some of the households specialized primarily irrigation dependent livelihoods while others gain their livelihood from a diverse range of livelihood activities but out of irrigation.

There are also households which diversified their livelihood as irrigation dependent and irrigation independent livelihoods which include both scenarios. Livelihood of households within the farming community was found to depend on diverse portfolio of activities and income sources. On-farm income (such as income from irrigated crop, rain-fed crop or livestock production/rearing), off-farm income (such as trading of agricultural products), and non-farm income (such as non-farm employment, non-farm trade), are the different income portfolios in which the households of the study area diversify their activities. The survey results found that there is a significant difference in mean total household income between irrigation user and non-user livelihoods. It is found that $10.8 \%$ of the irrigation users do not have any income from rain-fed crop production other than irrigation products. The results of the survey also compared that the ratio of mean total income of irrigation users to non-users exceeds by $37.03 \%$ and nutritional status and standard of living of the users also increased by the same factor as income.

Overall of $63.1 \%$ of the users and $67.7 \%$ of the non-users of small-scale irrigation do not participate in any offfarm activities. Thus, households depend for their livelihood on non-farm and on-farm income portfolios. With regard to livestock production as an onfarm income, irrigation dependent households gain income from livestock $13.8 \%$ more than irrigation non-users do. In relation to the above income portfolio and livelihood of the households, $56.9 \%$ of the users and $60 \%$ of the non-users of small-scale irrigation households do not have non- 
The Journal of Agricultural Sciences, 2012 vol. 7, nol

farm income and activities. Remittance also covers $1.5 \%$ and $2.2 \%$ of the total income of the users and non-users of small-scale irrigation respectively. Moreover, irrigation utilization greatly supports the livelihood of the non-users through employment opportunities.

\section{Social Participation and Access to Infrastructural Facilities}

Irrigation intensifies input and labor. Credit either in the form of cash or kind from different sources, is an important institutional service to finance poor farmers for input purchase and ultimately to adopt new technologies. However, some farmers have access and utilization to credit while others not, due to problems related to repayment and down payment in order to get input from formal sources. The survey indicated $78.4 \%$ of the non-users and $89.2 \%$ of the users of irrigation had utilized credit although the access is equal to all households without any difference. Credit non-user households reject credit utilization due to different reasons. The results contended that $7.7 \%$ of the users of irrigation, which spurn credit utilization, hardly faced any problem due to their limited need (unfelt need). On the other hand, 6.2\% and $7.7 \%$ of the non-users of irrigation eschew credit utilization due to their limited need and fear of failure to pay respectively. It is also found that $4.6 \%$ of the non-users of irrigation reserved from irrigation utilization due to expectations of high interest rates of the credit. An equal amount $3.1 \%$ of the users and non-users of irrigation restricted themselves from credit utilization due to religious restrictions locally called haram.

Rural farm households engage in different positions of informal and formal institutions such as Mahber, Idir, water user association, peasant association and wereda administration of their locality. The ratio of small-scale irrigation user households to non-user households who are in different positions of the community exceeds by $47.7 \%$. The main reason for the gigantic difference between irrigation user and non-user households in their position in the community is due to the access and utilization of information. Information on market prices and channels is one of the important aspects for livelihood improvement of rural farm households. Although information on marketing of irrigation products and agricultural inputs is a determinant factor for producers, only $75.4 \%$ of the irrigation users have access to information. As a source of information, $7.7 \%$ and $67.7 \%$ of them use telephone (fixed or mobile) and person to person information sharing respectively. This shows even in the age of information era, people in such areas are still using traditional way of information sources and means.On-farm income refers to the total income from irrigated and rain-fed crops. Similarly, off-farm income is a type of income which is derived from sources such as trading of agricultural products. The econometric results confirmed that there is a positive and significant relationship between onfarm income of households and irrigation participation at less than $1 \%$ significant level. 
Kinfe Aseyehegn, Chilot Yirga and Sundar Rajan

Table 03: Mean household income portfolios of the farm households in Ethiopian Birr

\begin{tabular}{|c|c|c|c|c|}
\hline Source of $i$ & ncome & Users & Non-users & T-value \\
\hline & Irrigation & 12934.98 & 0.00 & $10.169 * * *$ \\
\hline On-farm & & & & \\
\hline & Rain-fed & 5225.32 & 7084.61 & $-2.878 * * *$ \\
\hline & $\begin{array}{l}\text { Irrigation \& rain- } \\
\text { fed }\end{array}$ & 18160.31 & 7084.61 & $7.143 * * *$ \\
\hline & Livestock & 1864.46 & 1010.46 & $3.026 * * *$ \\
\hline & Total & 20024. 76 & 8091.07 & $7.497 * * *$ \\
\hline & $\begin{array}{l}\text { Expense for crop } \\
\text { prod. }\end{array}$ & 6695.76 & 2184.64 & $7.273 * * *$ \\
\hline & Net income & 12285.92 & 5878.73 & $6.065 * * *$ \\
\hline Off-farm & & 746.46 & 600.30 & 0.488 \\
\hline Non-farm & & 2023.07 & 2572.46 & -0.669 \\
\hline Remittanc & & 353.78 & 249.23 & 0.412 \\
\hline Property/ir & come & 33052.78 & 14318.91 & $2.723 * * *$ \\
\hline
\end{tabular}

\begin{tabular}{llll}
\hline Total income & $\mathbf{5 6 2 0 0 . 8 7}$ & $\mathbf{2 5 8 3 1 . 9 8}$ & $\mathbf{4 . 2 1 7} * * *$
\end{tabular}

$* * *$ and ${ }^{* *}$ statistically significant at less than $1 \%$ and $5 \%$ probability level respectively Source: Survey data, 2009

The positive effect between on-farm household income and participation in irrigation farming suggests that income derived from on-farm activities enables households to pay for farm inputs required for profitable irrigation farming. The marginal effect shows that as on-farm income of households increases by 100 Birr, the probability of a household's participation in smallscale irrigation increases by $1 \%$. However, off-farm income significantly and negatively influenced the likelihood of participation in irrigation-farming suggesting households engaged in off- farm activities are less likely to participate in irrigation farming. This negative relationship depicts the likelihood of participation in irrigation farming would be reduced by $1 \%$ for every 100 ETB earned from off-farm activities, as off-farm activities withdraw active labor from participating in irrigation. Higher market prices of irrigation products are likely to motivate farm households to participate in small-scale irrigation schemes. The marginal effect revealed that the probability of participation in irrigation for a household, with a reasonably good access to market 
The Journal of Agricultural Sciences, 2012 vol. 7, nol

information would by nearly twice than households who do not have access to market information. Similarly, household's residence to water sources is found to have a significant and negative relationship to the probability of participation in small-scale irrigation.

\section{Results of the probit model}

The negative sign indicates that the farther the water source is from a household's residence the lower the likelihood of participation in irrigation farming. Conversely, the nearer a household resides to a water source, the higher the probability of participating in irrigation scheme due to the fact that the opportunity cost of the time lost in travelling to and from an irrigation-farm for households located a short distance

Table 0 4: Maximum likelihood estimates of the probit model

\begin{tabular}{llll}
\hline & Coefficients & t-value & $\begin{array}{l}\text { Marginal } \\
\text { effect }\end{array}$ \\
\hline constant & -4.75882 & $-2.32099 * *$ & -1.5668 \\
education level & 0.012903 & 0.137887 & .0042 \\
family labor force & 0.168341 & 0.866935 & .0554 \\
age of the household head & 0.0335619 & 1.18129 & .0111 \\
on farm income & 0.000172252 & $2.81975 * * *$ & .0001 \\
of farm income & -0.000378195 & $-1.87574 *$ & -.0001 \\
nonfarm income & -0.000149225 & -1.26935 & .0001 \\
remittance & -0.000193725 & -0.901888 & -.0001 \\
property income & $7.08725 \mathrm{e}-006$ & 0.704812 & .0000 \\
distance from irrigation to market & 0.0357116 & 0.612217 & .0118 \\
distance from irrigation to home & -0.598272 & $-3.01655^{* * *}$ & -.1970 \\
rain-fed land & -1.48404 & -1.44643 & -.4886 \\
total livestock unit & -0.0461839 & -0.306553 & -.0152 \\
sex & 1.15819 & $1.70084 *$ & .3813 \\
market information & 4.73361 & $4.18098 * * *$ & 1.5585 \\
access to credit & -0.460747 & -0.589819 & -.1517 \\
health condition & 1.54415 & $1.98631^{* *}$ & .5084 \\
\hline Dependent variable & & Irrigation Participation \\
Weighting variable & & Decision & \\
Number of observations & & ONE & \\
Log likelihood function & & 130 & \\
Restricted log likelihood & & -19.87096 & \\
Chi-squared & & -90.10913 & \\
Degrees of freedom & & 140.4763 & \\
R-square & & .685043 & \\
\hline$* * *, * *$, and * indicate significance at less & & & \\
respectively. Source: Survey data, 2009 & & & \\
\hline
\end{tabular}


Kinfe Aseyehegn, Chilot Yirga and Sundar Rajan

from irrigation schemes would be much lower than households located much farther. Besides, the lower transaction cost households located near water sources enjoy, and also are likely to have a better awareness of the associated agricultural technologies due to their proximity. Keeping other variables constant at their respective mean level, the probability of participating in irrigation for a household increased by $19.7 \%$ as the distance of water source from his/her residence reduces by one kilometer.

Discussion with sample households and key informants revealed that maleheaded households hardly faced labor shortage for irrigation as well as rainfed farming due to physical, technological, socio-cultural and psychological fitness of farm instrument to males than females. Moreover, the income of male-headed households is higher, compared to female-headed households further increasing the comparative advantage of male-headed households to engage in irrigated farming than female-headed households do. The results of the econometric model proved that gender of the household is an important variable influencing the participation decision. The marginal effect of gender indicates that the probability of participation in irrigation for a male-headed household increases by $38.13 \%$ compared to a female-headed household, given other variables are kept at the average level. In addition to gender, the health status of a household is an important variable influencing participation in program interventions. Disease, disabilities and extra old age affect irrigation participation through reduction of active labor for production and adding expenses for medication. The positive and significant relationship of health status of the household head with participation in small-scale irrigation indicates that the probability of a household's participation in irrigation increases by $50.84 \%$ for a healthy household head compared to a household with poor health or with some type of disability.

\section{Model results of the second stage estimation}

The second stage of Heckman's procedure also referred to as the outcome or selection equation uses Ordinary Least Square (OLS) for analyzing household total income as a measure of household income. The likelihood function of the two-step Heckman model was significant showing a strong explanatory power. Also, the coefficient of the Inverse Mills Ratio (IMR) was significant $(\mathrm{P}<0.0000)$ providing evidence for the presence of self-selection and hence justifying the use of Heckman's two-step procedure.

Land and livestock are key assets of rural farm households. A unit increase in irrigable land of a household increases total income of the households by Birr 23,327.8. In other words, irrigation user households with onehectare irrigable land are better off in their income by Birr 23,327.8 than nonuser households. Access to irrigable land by allowing households to use 
The Journal of Agricultural Sciences, 2012 vol. 7, nol

family labor and other farm resources more intensively makes households more productive and hence better off. The results further indicate one unit increase in the active labor force of an average household would raise the total income of the household by Birr 3987.14. In the same way livestock holding measured in Tropical Livestock Unit (TLU) is found to have a positive and significant influence on income of households. A unit TLU increase in livestock holding would increase the total income of a household by Birr 8446.62, other factors being constant. Livestock, besides its direct role in raising agricultural productivity, helps households stabilize consumption by absorbing income shocks that might arise from crop failures triggered by natural disasters. Oxen are the sole draught power sources and hence lack of oxen besides its negative effect on land productivity signifies a lower economic status of farm households. Households who do not own oxen either acquire the much needed pair of oxen at a cost or forced to share/ rent out their land, which means a substantial reduction in income. Households with larger number of livestock particularly oxen, therefore, are likely to raise farm income for they can use other farm inputs more efficiently by bringing additional land into cultivation through either cash rent or share cropping basis. Participation in small-scale irrigation has a profound positive effect on household income. This evidenced as, keeping others constant, the total income of irrigation user households would be higher by Birr 26,593.60 than households who do not participate in irrigation farming. Irrigation allows farm households to use farm resource in a more productive way in at least two ways. First, it enables the production of vegetables and cereal crops twice and sometimes three times a year. Second, it helps improve livestock productivity by providing feed during the dry seasons and minimizing the cost of paying for fodder. Participation in small-scale irrigation, therefore, enables farm households to improve their well-being by not only allowing higher income but also minimizing risk and smoothening household consumption. However, information on markets is a determinant factor for irrigation technology adoption. Consequently, access to market information is found to influence income and hence well-being, significantly. The results indicated total income of farm households who have access to market information exceeds by Birr 23,749.8 than households deficient in market information. Market information helps farm households to market perishable farm products at the right time without loss of quality. Access to market information would also play a key role by providing accurate information on the demand and supply of farm inputs and outputs. But, having information only may not result in adoption and utilization of smallscale irrigation whenever inputs and services are lacked or limited. This gives direction to the importance of access and utilization of credit in enhancing the adoption of new agricultural technologies including irrigation among farm household. 
Kinfe Aseyehegn, Chilot Yirga and Sundar Rajan

\begin{tabular}{lll}
\hline \multicolumn{2}{l}{ Table 05: Estimates of the ordinary least square model variables } \\
\hline & Coefficients & t-value \\
\hline constant & -14126.4 & -0.77609 \\
education level & 301.33 & 0.264576 \\
family labor force & 3987.14 & $1.83902^{*}$ \\
age & -245.765 & -0.882815 \\
remitance & -1.06985 & -0.480205 \\
distance of irrigation to home & 1640.1 & 1.06658 \\
irrigated land & 23327.8 & $1.77496^{*}$ \\
total livestock unit & 8446.62 & $5.81036^{* * *}$ \\
irrigation participation & 26593.6 & $1.68018^{*}$ \\
sex & 4401.14 & 0.52642 \\
market information & 23749.8 & $1.98626^{* *}$ \\
access to credit & 23783.8 & $2.70915^{* * *}$ \\
health condition & -8071.85 & -1.08897 \\
lambda & -18982.9 & $-1.72542^{*}$ \\
\hline Dependent variable & TOTAL INCOME Mean= & 41016.43077 \\
Weighting variable & None & \\
Number of observations & 130 & \\
Log likelihood function & -1533.6329 & \\
Restricted (b=0) log-L & -1572.8541 & \\
Adjusted R-square & .39238 & \\
R-square & .453052 & \\
Prob. Value & 0.00000 & \\
\hline
\end{tabular}

***, **, and *statistically significant at less than $1 \%, 5 \%$, and $10 \%$ level respectively.

Source: survey data, 2009

According to the results, the income of households who have access to and utilized credit would be higher by Birr 23,783.8 compared to households who do not have access to credit.

\section{CONCLUSIONS}

Irrigation intensifies input and labor throughout the year. It motivates selfemployment offsetting fulltime and part

time off-farm or nonfarm employment due to efficient utilization of labor. This indicates off-farm income inspires to withdraw active labor force from irrigation activities and placing to offfarm income driving activities reduces irrigation participation of farm households. Farm households that have access to market information are able to compare, the net income from rain-fed and irrigation farming. Moreover, it assists purchasing of the right input at the right time from the right enterprise 
The Journal of Agricultural Sciences, $2012 \mathrm{vol}$. 7, no1

and supplying of the products to the right customer with a reasonable intermediary cost. However, the gender difference of household heads in irrigation participation indicated female-headed households face shortage of labor and market information, made them rent/share out their land. Networking of rural farm households with their customers through information sources such as mobile and telephone service is a determinant factor. Accessing of labor saving technologies easily managed by women solves the workforce problem of female-headed households. Special attention for female-headed households, considering their gender mainly in criteria of accessing irrigable land facilitates women participation in irrigation. Insuring property ownership of female-headed households through credits and self-help groups is the other mechanism of increasing female-headed household's participation in irrigation.

Access of farm households to irrigated land enables them to diversify their income sources, including non-farm and off farm livelihood activities, and to make savings. Livestock serve as a source of income and draft power. Wealth status of households is determined by the livestock, they owned mainly oxen. Crop failure risk is minimized if the household owned livestock due to expectations of compensating failed crop through sale of their livestock. Credit is an important institutional service to finance poor farmers for input purchase and ultimately to adopt new technology. Saving livestock from sale and land from rent out or shared out, at uncertain seasons is doable due to credit utilization. Although increasing the total land size is infeasible, replacement of the rain-fed land by irrigable land through development of new dams and applying different irrigation technologies is crucial. Therefore, due attention to livestock production through introduction of zero grazing systems to make livestock production is friendly with environment and ecology conservation is vital. Microfinance institutions are better to provide credit, at reasonable interest rate, and at the right time credit be demanded at places where farm households can access easily.

Household members, who are free of disease, and disabilities, have productive labor for irrigation. The burden of caring and treating sick, disabled or extra old age reduces the active labor for irrigation not only labor of the diseased or disabled individual, but also labor of the other members of the household that leads to double sentence. Provision of social services such as health center and road at village level is essential in changing the life of the farm households. Informal education on health aspects, nutrition, hygiene and sanitation also play a role in preventing and curing of disease. 



\section{REFERENCES}

Desta Beyera, (2004). Impact of Community Managed Irrigation on Farm Efficiency and Household income; the case of Weliso and Wenchi Districts of Oromia. Unpublished M.Sc Thesis, Haramaya University.

Ersado Lire, G. S. Amacher and J. Alwang, (2004). Productivity and land enhancing technologies in northern Ethiopia: Health, public investments, and sequential adoption. American Journal of Agricultural Economics, 86(2): 321-331.

Ersado Lire, (2005). Small Scale Irrigation Dams, Agriculture Production, and Health: Theory and Evidence from Ethiopia. World Bank Policy Research Working Paper 3494. The World Bank: Washington DC.

FAO (Food and Agricultural Organization), 2003 . Irrigation in Africa South of the Sahara. FAO Investment Center Technical Paper 5. FAO: Rome.

MoWE, (Ministry of Water and Energy), 2011. Water and Development quarterly bulletin 5. MWR: Addis Ababa.

Wooldridge, M. (2002). Econometric Analysis of Cross Section and Panel Data . Massachusetts Institute of Technology: London.

Zaman, H. (2001). Assessing the poverty and vulnerability effect of micro credit in Bangladesh. pp. 34-36. A case study of BRAC. Office of the chief economist and senior vice president (DECVP), The World Bank: Dhaka. 